\title{
The Influence of Colour on the Malaysia SMEs Logo: The Most Often Selection of Colour
}

\author{
Muh Sarip Abd Rahman \\ Department of Art Foundation, Faculty of Art \& Design \\ Universiti Teknologi MARA, 32610 Seri Iskandar, Perak, Malaysia \\ Tel: 60-13-810-8281 E-mail: saripman24@gmail.com
}

Mohamad Noorman Masrek

Accounting Research Institute

Universiti Teknologi MARA, 40000 Shah Alam, Selangor, Malaysia

Tel: 60-19-341-0524 E-mail: mnoormanm@gmail.com

Muhamad Abdul Aziz Ab Gani

Department of Graphic \& Media Digital, Faculty of Art \& Design

Universiti Teknologi MARA, 32610 Seri Iskandar, Perak, Malaysia

Tel: 60-13-518-1311Ｅ-mail: duzeezdugani.designstudio@gmail.com

\author{
Ishak Ramli (Corresponding author) \\ Department of Fine Art, Faculty of Art \& Design \\ Universiti Teknologi MARA, 32610 Seri Iskandar, Perak, Malaysia \\ Tel: 60-13-282-5913 E-mail: ibr_86@yahoo.com
}

Received: September 9, 2014 Accepted: December 12, 2014 Published: February 1, 2015 doi:10.5296/jmr.v7i2.6990

URL: http://dx.doi.org/10.5296/jmr.v7i2.6990

\section{Abstract}

Colour is an element that plays a very significant role in every aspect of our life. With the 
realization on the importance of colour, the exploration and research on colour have introduced colour theories that have been applied and adapted until to this day. Through literature review, the previous researcher, has done the research on the influence of colour on the logo of the Bumiputra Companies, with the emphasize on Malay, and his findings showed that blue is the top choice selected and the most dominant colour used on the logos by the Malay Companies and followed by red and green. Nevertheless, the research scope is only look at Malay Companies and the findings are limited. However this paper reports and discusses the findings of one thousand (1000) by local companies, particularly under the category of SME (small and medium enterprises). The findings show there is a difference between previous findings. Red is a most dominant colour used on logos by Malaysia SMEs Companies and subsequently blue and white colour. Recommendations for further research are also discussed in an effort to improve the quality of local brands internationally.

Keywords: Colour, Logo, Small and Medium Enterprise 


\section{Introduction}

Colour plays an important role in every aspect of our lives. In fact, colour can help and facilitate us to know and distinguish an object to another and further makes an object more appealing (Ockvirk, O, G., Stinson, R, E, Wigg, P, R., Bone, R, O., Cayton, D, L., 1998). Colour is actually an effect of light having different wavelengths reflected by an object received by the eye (Alexander, T., 1984). However, in scientific terms, Ockvirk, O, G., Stinson, R, E, Wigg, P, R., Bone, R, O., Cayton, D, L. (1998) consider that colour is actually due to the visual response to wavelengths of light, known as red, yellow, blue, and so forth.

The role of the use of colour is not limited only in the field of art, but other areas as well as Eisman (2000) stated that the colours have a significant contribution in areas such as business, production, marketing, medicine, education and manufacturing.

In the context of branding, Rowden (2000) have explained that the colour is an important aspect in shaping the identity of a brand. We can see several examples of corporate giants like IBM, which is synonymous with the term 'Big Blue' and Coke which is famous for its red colour also symbolizes joy. This is why Eisman (2000) pointed out that colour plays an important role in every aspect of life.

As known earlier, a brand should have its own identity to distinguish it from other brands or competitors. Rowden (2000), have clearly pointed out that colour is essential aspect in this role. Thus, this research focuses on the aspects of frequently used colours in the Malaysian companies' logos under the SME category. This research is actually a continuation of previous studies by Ab. Gani, M, A, A., (2006) in which he had looked into the used of colours in Bumiputera owned companies' logos, especially the Malays.

\section{Problem Statement}

Without a doubt, studies or researches on colours is a broad subject, not just throughout the world, but also in Malaysia. As explained earlier, this research is a continuation of previous studies by Ab. Gani, M, A, A., (2006) in which he has made a study of 418 Malay companies and the research has focused on the colours most commonly used in Malay companies' logos. His overall findings are shown in table 1 below:

Table 1. Source from Ab. Gani, M, A, A., (2006)
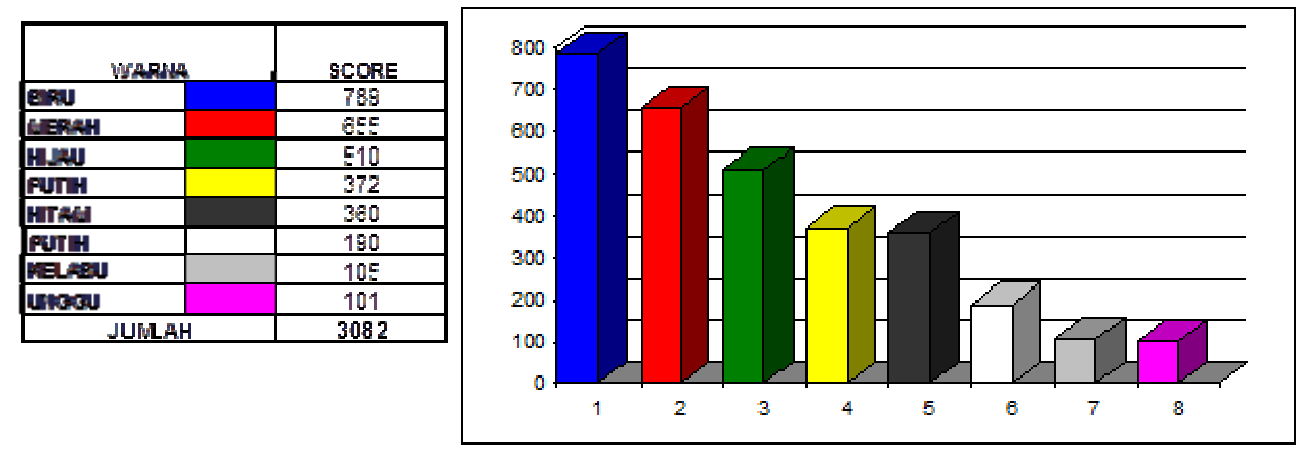
Although research related to colours, especially in Malaysian context has been made, there are still rooms for improvement. Based on this reason and principle, the purpose of this research is not to deny the credibility of earlier studies, but to make improvements, particularly on aspects that were covered or the researcher didn't get the opportunity to review. This is consistent with what has been stated by the Ab. Gani, M, A, A., (2006) that his research was the first step in researching on the use of colours by focusing the choice of colours by the Malays and hoping that later studies will look at a broader aspects.

The focus of improvement in this research is in terms of scoping, whereby the previous study focus only on Malay companies and it is limited to 418 companies. In this research, 1000 logos from the companies under the SME category in Malaysia have been collected and analyzed.

\section{Objectives}

Because the nature of this research is to provide improvement based on previous studies, thus the main objective of this research is to know the frequently used colours in company's logos under the category of SME companies in Malaysia. Secondly is to make a comparison between this research's findings, which is the frequently used colours in company's logos under the category of SME companies in Malaysia to the frequently used colours in company's logo owned by the Malays (Ab. Gani, M, A, A., 2006).\#

\section{Methodology}

\subsection{SME logos collection in Malaysia}

In the effort of collecting 1000 logos under the category of SME companies in Malaysia, the official directory of SME (2010) were used to obtain website addresses of companies from different categories. Their official websites were visited in which the logo were obtain and used for reference.

\subsection{Method of assessment of colour in the logo}

The method used by previous study (Ab. Gani, M, A, A., 2006) has been adopted and some modification were made to the previous table as in table 2 and 3 below:

Table 2. Analysis table (Ab. Gani, M, A, A., 2006)

\begin{tabular}{|c|c|c|c|c|c|c|c|c|c|c|}
\hline \multicolumn{11}{|l|}{ Method } \\
\hline \multirow{3}{*}{$\begin{array}{l}\text { Company } \\
\text { Name }\end{array}$} & \multirow{3}{*}{$\begin{array}{l}\text { Telehone } \\
\text { Number }\end{array}$} & Grey & Purple & Blue & Green & Red & Yellow & Black & While & \multirow{3}{*}{ Note } \\
\hline & & & & & & & & & & \\
\hline & & A & B & C & D & $\mathbf{E}$ & $\mathbf{F}$ & G & H & \\
\hline Internet & & & & & & & & & & \\
\hline
\end{tabular}


Table 3. Modified table

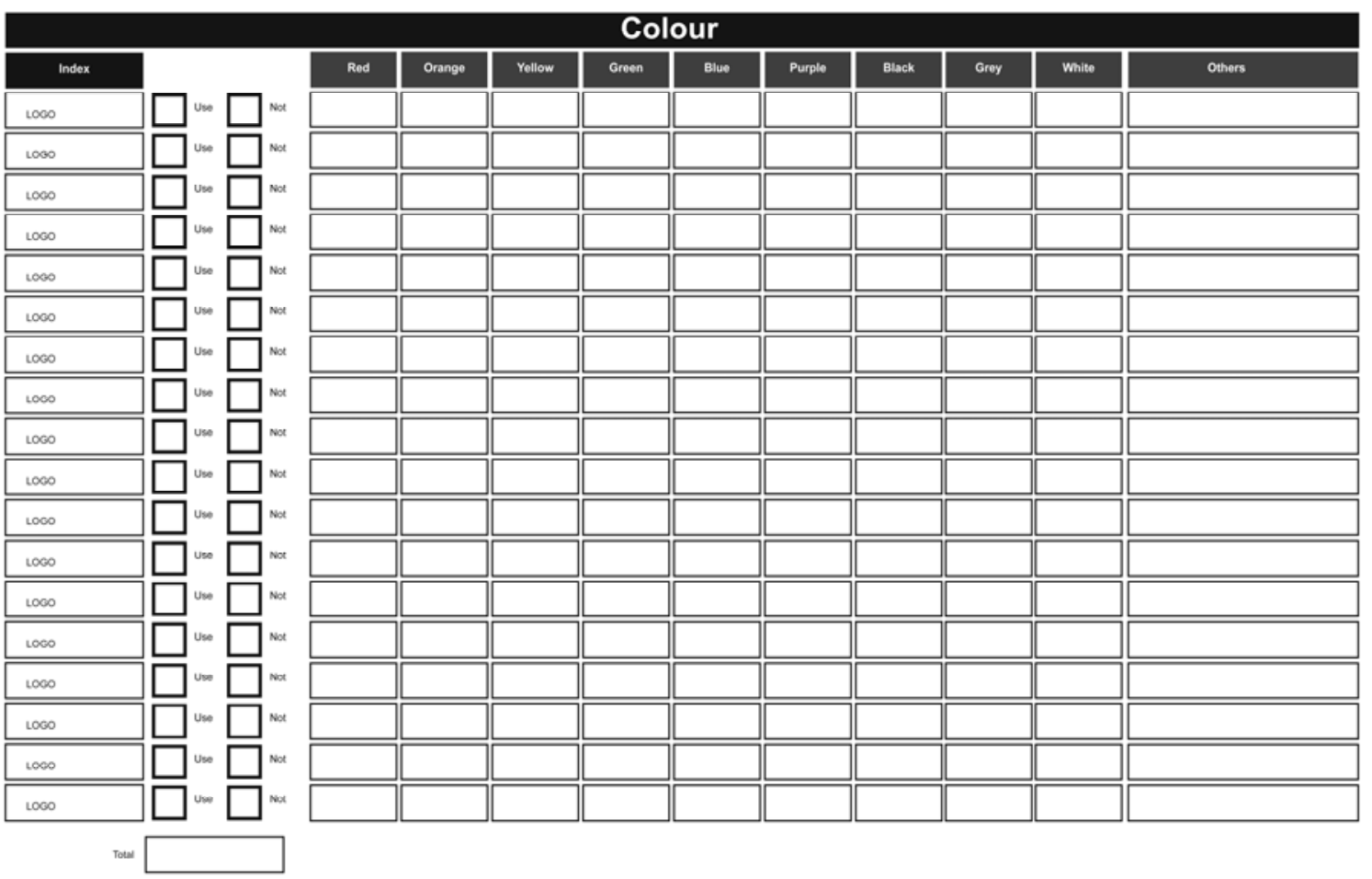

Based on the modified table in table 3 above, there are 9 categories of colour are being assessed compared to only 8 in the original table in the figure 2 above. According to Ab. Gani, M, A, A., (2006), to determine the frequency and level of dominance of a colour, a scoring method was used. In addition, there are some important colours such as orange, brown, gold and silver need to be classified and categorized as well. Although Hardin (1997) explained that based on the theory of Charles Sternheim, orange colour does not need to be categorized as a separate colour. Instead, red and yellow are sufficient to represent the colour orange. However, in this research, orange will be classified as its own category to be evaluated in order to avoid confusion.

For the colour gold and silver, for the purpose of this research, it is classified as yellow category. Based on the Fehrman (2000), gold is a new colour as a result of the advances in colour technology. In fact, the name of the colour is taken directly from the objects of gold itself. The definition of gold, according to Iskandar (1984) in the Dewan dictionary is an expensive yellow logo. Brown is also in the Malay community are classified under the category of yellow (Jamal, 1992).

In this research, the same scoring method as previous research (Ab. Gani, M, A, A., 2006) is used to find out the frequency and the dominance of a colour. A dominant colour was given 3 points, 2 points for the lesser dominant colour and 1 point for the colour that is not dominant. Scoring method is important to determine: 


\section{Macrothink}

4.2.1 Dominance level of a colour

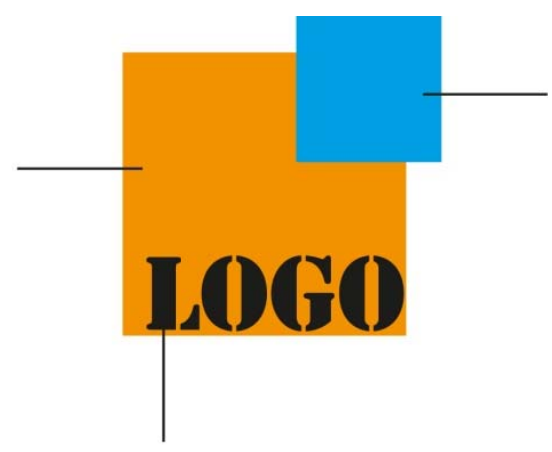

Figure 1. Sample for Determine Colour

In research context, by observing the colours used in logos of the companies under the SME category, it can be difficult to obtain and measure the exact proportion of colours used in a logo. However, it is much easier and effective if assign a colour a score based on the level of dominance. Visual in Figure 1 above shows the colour orange is the most dominant colour (3 points), followed by black ( 2 marks) and the blue colour is not dominant (1 mark).

\subsubsection{Frequency of colours used}

Frequently used colour is not necessarily the dominant colour. This is because, there are colours often used in a logo but it is not dominant. On the other hand, there are dominant colours in a logo, but not frequently used at all. All of these phenomena will be presented in the final results after scoring table as figure in 3 are completed.

\section{Analysis \& Finding}

In this section, the findings from the analysis of colours used in 1000 logo under the category of SME companies in Malaysia are presented and discussed. A comparison with previous findings (Ab. Gani, M, A, A., 2006) is also reviewed and discussed. Initial finding of the colours that are frequently used and dominating in logos under the category of SME companies in Malaysia are shown in the table and chart in table 4 and 5 below:

Table 4. Frequency of colours used in a logo(number of times)

Colour Application in 1000 Logo
\begin{tabular}{|l|c|c|}
\hline Colour & Apply & $\%$ \\
\hline Red & 456 & $46 \%$ \\
\hline Orange & 91 & $9 \%$ \\
\hline Yellow & 189 & $19 \%$ \\
\hline Green & 245 & $25 \%$ \\
\hline Blue & 366 & $37 \%$ \\
\hline Purple & 52 & $5 \%$ \\
\hline Black & 328 & $33 \%$ \\
\hline Grey & 120 & $12 \%$ \\
\hline White & 464 & $46 \%$ \\
\hline Brown & 34 & $3 \%$ \\
\hline
\end{tabular}

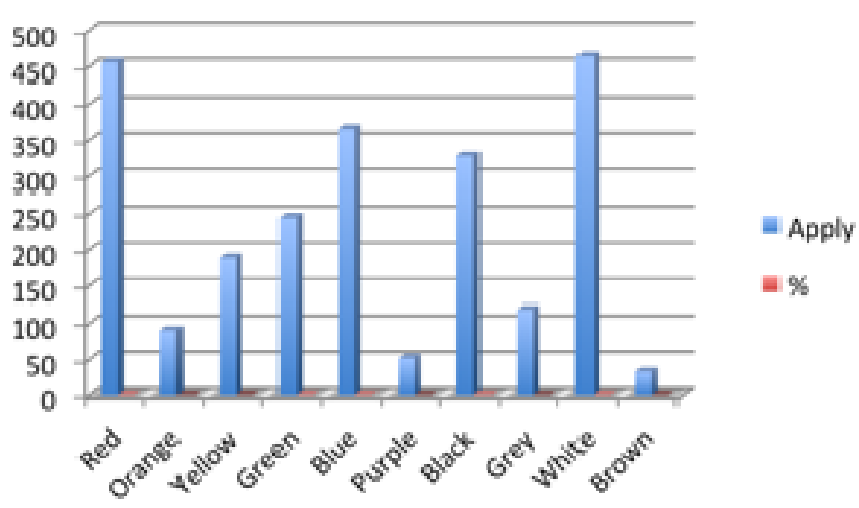


Table 5. Colour application ant the total score

Total Score of Colour Application

\begin{tabular}{|l|c|c|c|c|}
\hline Colour & Score3 & Score2 & Score1 & Total \\
\hline Red & 708 & 330 & 55 & 1093 \\
\hline Orange & 96 & 62 & 28 & 186 \\
\hline Yellow & 177 & 166 & 47 & 390 \\
\hline Green & 426 & 140 & 33 & 599 \\
\hline Blue & 717 & 176 & 39 & 932 \\
\hline Purple & 69 & 42 & 8 & 119 \\
\hline Black & 378 & 226 & 89 & 693 \\
\hline Grey & 114 & 94 & 35 & 243 \\
\hline White & 321 & 486 & 114 & 921 \\
\hline Brown & 72 & 10 & 5 & 87 \\
\hline
\end{tabular}

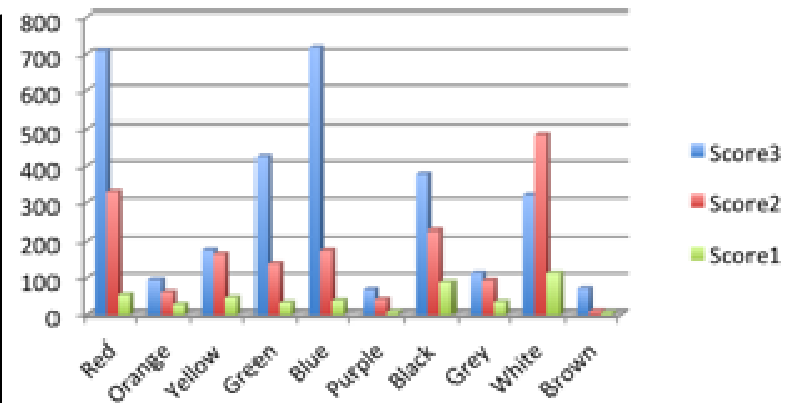

Based on the table and charts above, we can see that red and white are the most frequently used colour with an equal percentage of $46 \%$. In actual, white is actually ahead of red with a total of 464 times used, compared to 456 times for red. This is followed by blue and black. This finding clearly contradicting to the finding of previous study (Ab. Gani, M, A, A., 2006), in which blue is the most frequently used colour, followed by red, green, yellow and black.

In contrast, table 5 clearly show that blue is the most dominant colour, with a total of 717 points from the most dominant category ( 3 points) followed by 708 points for red, and green are next in line with 426 points. Black leads white with 378 versus 321 points.

However, white has the highest collected points used for the lesser dominant colour (2 points) with a total of 486 points while the total points for the colour red is 330 . This phenomenon pushes white to the third highest overall points behind the red and blue, which is 921 points compared to 1093 and 932 points. This phenomenon clearly shows that a dominant colour in a logo does not necessarily mean that it is the most frequently used colour. White is frequently used as the colour that is less dominant and not dominant. In line with the opinion of Samara (2007), based on colour model, he is in the opinion of white is a lack of colour, but psychologically white brings calmness and relaxedness. In addition, it is neutral colour. Therefore, the use of white in a logo serves as a complementing and neutral factor in balancing other colours.

Overall, red is the most dominant colour used in logos under the category of SME companies in Malaysia with 1093 overall points. Blue is behind red with 932 points. White collected 921 points after blue. Black (693 points), green (599 points), yellow (390 points) and gray (243 points) each behind white in fourth place, five, six, and seventh. While the colour orange (186 points), purple (119 points), and brown ( 87 points) is the colour that is not frequently used and not a dominant colour in the context of its usage in logos under the category of SME companies in Malaysia.

Based on findings of the colours that are often used in logos of the companies under the category of SMEs in Malaysia, the research will compare it with previous findings by $\mathrm{Ab}$. Gani, M, A, A., (2006) as a summary of this research and shown in Table 6 below: 


\section{Macrothink}

Table 6. Comparison Findings charts

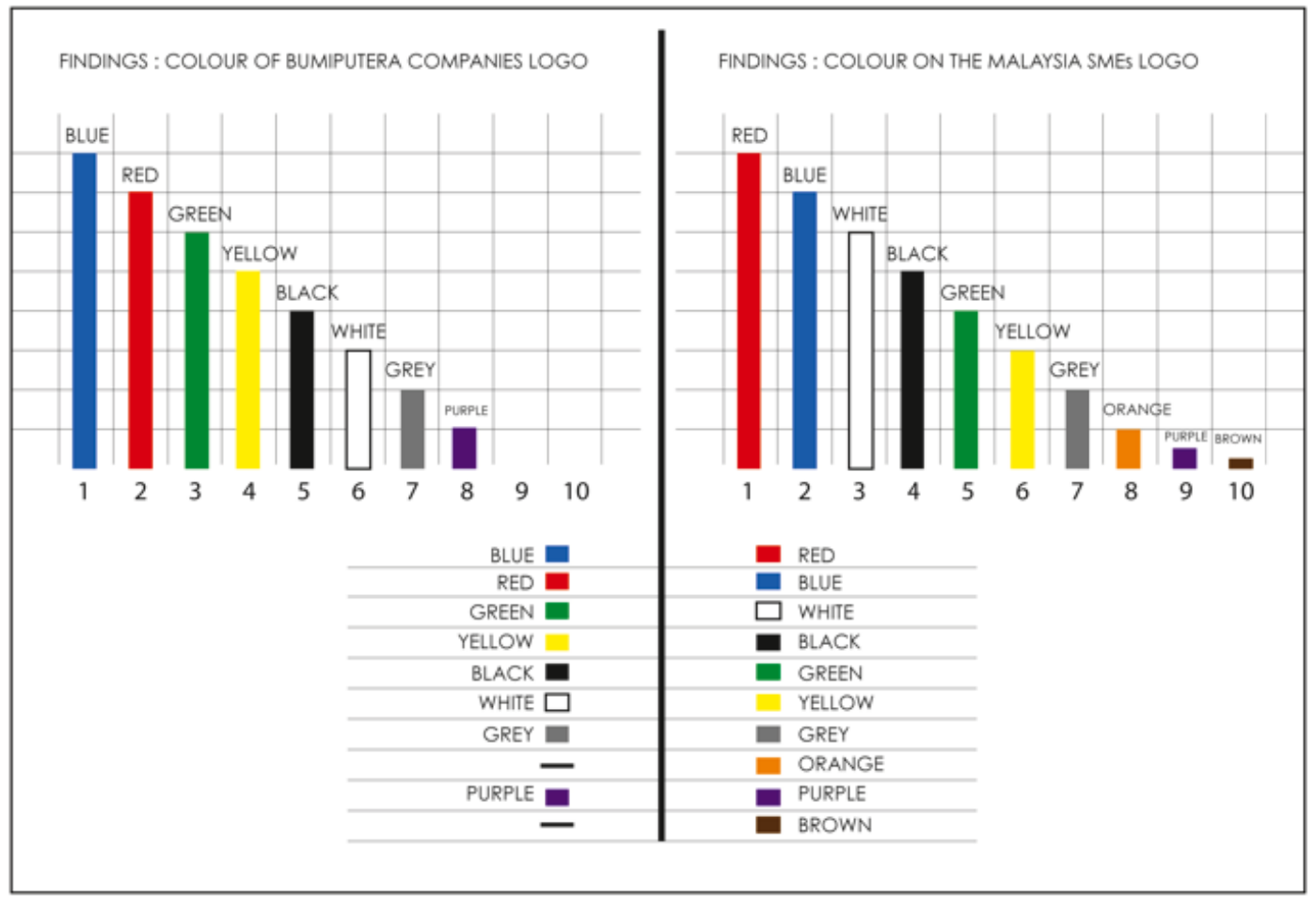

\section{Discussion \& Conclusion}

Based on the chart in table 6 above, we can see that in general the top six colours in both of the above chart did not have much in common in terms of frequency used, except for the last two colours which are gray and purple.

Red is the most frequently used colour. In fact, it even dominates the usage in logos under the category of SME companies in Malaysia. On the other hand, the colour blue is the colour most frequently used in Malays (Bumiputra) company logos. This also shows the use of colour in the logo when viewed in a larger scope, for example the logos under the category of SME companies in Malaysia, the result will be different when compared to the result focuses only on one category, namely Bumiputra. Furthermore, Ahmad (1993), Fehrmen (2000) and Eiseman (2000) have agreed that the psychologically, red have the nature of strength and confidence. Therefore, the usage of red in a logo will make the logo more convincing and powerful.

According to Ab. Gani, M, A, A., (2006), from the survey that was conducted on 340 individuals, found out that the majority of the Malays, which is 140 of them (33\%) think and feel that blue is the colour that symbolizes Malay identity. This clearly refelcted in the findings of the most common colour used in the Malay company logos. The usage of the colour blue in a logo in wider scope is still common, for example blue is the colour of the second highest in terms of frequency used in the logos under the category of SME companies in Malaysia. This is also consistent with the view of Samara (2007) that the colour blue is a 
common, peaceful and a popular colour.

Third highest in terms of colour frequencies in Malay companies logos is green while white hold the same position in the SME companies in Malaysia. Black is the fourth highest in the company logos SME in Malaysia, followed by green and yellow colours. While yellow is the fourth highest colour used in logos by the Malay, followed by black and white. Purple and gray is a remote colour and seldom used in the logos of both categories of companies.

In conclusion, the choice of colour or frequency of use of a colour in a logo may not be consistent, as shown in this research finding that indicate that at a broader scope, the findings of a research may be different. On this basis, it is hoped any future research will be able to see something more significance. Colours used in the company logos by ethnic groups category in Malaysia is an aspect that should be taken into account in future studies in order to improve the selection of colours in a logo which is also the key, in Wheeler's view (2003), in introducing a brand to the international level.

\section{Acknowledgement}

The research is financed by Universiti Teknologi MARA, Seri Iskandar, Perak. (Ref: 600-KPK(PJI.5/1/4)

\section{References}

Ab. Gani, M, A, A. (2006). Pengaruh warna citarasa orang Melayu pada logo dan identiti syarikat Melayu. Universiti Sains Malaysia. Pp.7, 8, 14, 120.

Eiseman, L. (2000). Pantone, Guide To Communication With Colour. Ohio: North Light Books. Pp.7, 8, 14, 120

Fehrman, R. K. (2000). Colour The Secret Influence. New Jersey: Prentice Hall. Pp. 47, 49, 150, 185, 195, 207.

Hardin, C.L., \& Maffi, L. (1997). Colour categories in thought and language. New York: Cambridge University Press. P.136. http://dx.doi.org/10.1017/CBO9780511519819

Ahmad, N. (1993.) Komunikasi Visual, Teknik fotografi warna. Kuala Lumpur: Dewan Bahasa Dan Pustaka. Pp. 18, 20, 22, 24.

Orvirk, O.G., Stinson, R.E., Wigg, P.R., Bone, R.O., \& Cayton, D.L. (1994). Art Fundamental, Theory \& Practice, Seventh edition. Ohio: WCB Brown \& Benchmark. Pp. $139,142,143,156,158$.

Rowden, M. (2000). The Art Of Identity, Creating and managing a successful corporate identity. England: Gower Publishing Limited. Pp. vii, 1, 143, 146, 151, 153.

Samara, T. (2007). Design Elements, A Graphic Style Manual. Rockport Publishers, Inc. Pp. $110,111$.

SMI/SME. (2010). The Official Business Directory of SMI Association of Malaysia, 8th Edition.

Syed Ahmad Jamal. (1992). Rupa Dan Jiwa. Kuala Lumpur: Dewan Bahasa Dan Pustaka. Pp. 23, 25, 27, 28. 


\section{Macrothink}

Teuku Iskandar. (1994) Kamus Dewan. Kuala Lumpur: Dewan Bahasa dan Pustaka. Pp. 286, 752, 810, 820, 868, 1155, 1347.

Wheeler, A. (2003) Designing Brand Identity. A complete guide to creating, building, and maintaining strong brands. John Wiley \& Sons, Inc. Pp. 4Strunk, W., Jr., \& White, E. B. (1979). The elements of style (3rd ed.). New York: Macmillan, (Chapter 4).

Van der Geer, J., Hanraads, J. A. J., \& Lupton R. A. (2000). The art of writing a scientific article. Journal of Scientific Communications, 163, 51-59

\section{Copyright Disclaimer}

Copyright for this article is retained by the author(s), with first publication rights granted to the journal.

This is an open-access article distributed under the terms and conditions of the Creative Commons Attribution license (http://creativecommons.org/licenses/by/3.0/). 